\title{
PENGEMBANGAN LEMBAR KERJA PESERTA DIDIK BERDASARKAN KERAGAMAN JENIS TANAMAN DI GREEN CHEMISTRY DAN KEBUN BIOLOGI UNIVERSITAS BENGKULU
}

\author{
Orin Uniati ${ }^{*}$, Dewi Jumiarni ${ }^{1}$, Ariefa P. Yani ${ }^{1}$ \\ ${ }^{1}$ Program Studi Pendidikan Biologi, Fakultas Keguruan dan Ilmu Pendidikan, Universitas Bengkulu \\ email: orinuniati.ou@gmail.com
}

\begin{abstract}
Abstrak
Keanekaragaman hayati Indonesia dapat dijadikan sebagai sumber belajar dan dikembangkan menjadi bahan ajar bagi peserta didik. Melalui penelitian ini, akan dikembangkan bahan ajar berupa Lembar Kegiatan Peserta Didik (LKPD) berdasarkan sumber belajar berupa keanekaragaman tanaman di Green Chemistry dan Kebun Biologi Universitas Bengkulu. Tujuan penelitian yaitu: 1. Mengetahui jenis-jenis tanaman yang terdapat di Green Chemistry dan Kebun Biologi Universitas Bengkulu; 2. Mengetahui kelayakan LKPD materi Keanekaragaman Hayati berdasarkan hasil observasi jenis-jenis tanaman yang terdapat di Green Chemistry dan Kebun Biologi Universitas Bengkulu; dan 3. Mengetahui keterbacaan LKPD materi Keanekaragaman Hayati berdasarkan hasil observasi jenis-jenis tanaman yang terdapat di Green Chemistry dan Kebun Biologi Universitas Bengkulu. Jenis penelitian ini adalah penelitian dan pengembangan atau Research and Development (R \& D) dengan tujuh langkah penelitian yaitu: 1. Potensi dan Masalah; 2. Pengumpulan Data; 3. Desain Produk; 4. Validasi Desain; 5. Revisi Desain; 6. Uji Coba Produk; dan 7. Revisi Produk. Data jenis tanaman yang terdapat di Green Chemistry dan Kebun Biologi Universitas Bengkulu selanjutnya didesain menjadi LKPD. LKPD yang telah didesain diuji validasi oleh validator dan uji keterbacaan oleh peserta didik. Berdasarkan hasil penelitian, diperoleh 73 jenis tanaman di Green Chemistry dan Kebun Biologi Universitas Bengkulu. Berdasarkan hasil uji validitas oleh validator, LKPD termasuk kriteria sangat valid dengan presentase $88 \%$. Berdasarkan hasil uji keterbacaan oleh peserta didik, LKPD termasuk kriteria sangat baik dengan presentase $93 \%$.
\end{abstract}

Kata Kunci : Lembar kegiatan peserta didik (LKPD), keragaman tanaman, green chemistry, kebun biologi

\begin{abstract}
Indonesian's biodiversity can be used as learning resources and developed into learning materials. This research aims to develop a student worksheet based on biodiversity of plant in "Green Chemistry and Biological Garden", University of Bengkulu. The specific target of this research are: 1. Identifying biodiversity of plants in Green Chemistry and Biological Garden, University of Bengkulu; 2. Finding out the eligibility of designed worksheets as a learner material on biological diversity based on the biodiversity of plants in Green Chemistry and Biology, University of Bengkulu; and 3. Finding out the readability of the designed student worksheet as a learner material on biological diversity based on the biodiversity of plants in Green Chemistry and Biology, University of Bengkulu. Biodiversity of plants in Green Chemistry and Biological Garden University of Bengkulu were designed into activity sheet learners. A designed worksheet then was validated by validators and was readability tested into the students. Based on research results, there are 73 kinds of plants in Green Chemistry and Biological Garden University of Bengkulu. A designed student worksheet was categorized as very valid (score $88 \%$ ) by the validators. This student worksheet also was marked as very well on readability test with satisfied percentage is $93 \%$.
\end{abstract}

Keywords: Student worksheet, plant biodiversity, green chemistry, biological garden 


\section{PENDAHULUAN}

Indonesia merupakan negara yang kaya akan keanekaragaman hayati baik flora maupun fauna. Keanekaragaman hayati yang berlimpah di Indonesia dapat dimanfaatkan bagi dunia pendidikan sebagai sumber plasma nutfah dan keilmuan (Nurhayati dan Wijayanti, 2016:58). Namun demikian, hingga saat ini keanekaragaman hayati di Indonesia belum umum dimanfaatkan sebagai sumber belajar. Potensi keanekaragaman hayati Indonesia dapat dimanfaatkan dalam dunia pendidikan sebagai sumber belajar dengan pendekatan lingkungan (Uno dan Mohamad, 2014:146).

Berdasarkan pengalaman peneliti saat magang I, II, dan III di beberapa sekolah menengah pertama Provinsi Bengkulu, para guru belum menggunakan sumber belajar dari lingkungan sekitar karena dianggap merepotkan. Padahal penggunaan lingkungan sebagai sumber belajar memiliki berbagai kelebihan (Uno dan Mohamad, 2014:146147). Penggunaan lingkungan sebagai sumber belajar dapat dilaksanakan oleh guru jika sumber belajar tersebut dikembangkan menjadi suatu bahan ajar.

Selama ini, paradigma dan persepsi umum yang melekat di kalangan para pendidik adalah membuat bahan ajar merupakan pekerjaan yang sulit (Prastowo, 2011:14). Hal inilah yang menyebabkan guru saat ini tidak menggunakan bahan ajar buatan sendiri, melainkan menggunakan bahan ajar buatan orang lain ataupun penerbit. Bahan ajar yang paling ideal adalah bahan ajar buatan guru (Republika, 2015:1). Salah satu bahan ajar yang dapat dibuat oleh guru yaitu Lembar Kegiatan Peserta Didik (LKPD). LKPD saat ini pada umumnya dibeli dan bukan dibuat sendiri oleh guru. Berdasarkan berbagai permasalahan diatas peneliti bermaksud untuk mengembangkan LKPD berdasarkan sumber belajar lingkungan sekitar.

Penelitian ini menggunakan lingkungan sekitar yaitu Green Chemistry dan Kebun Biologi Universitas Bengkulu (UNIB) dikarenakan lingkungan tersebut memiliki keanekaragaman tanaman yang cukup tinggi. Total terdapat 82 jenis tanaman di Green Chemistry dan Kebun Biologi UNIB. Lebih lanjut, jenis tanaman di Green Chemistry dan Kebun Biologi UNIB mengalami pertambahan setiap tahunnya. Oleh sebab itu, keragaman tanaman di Green Chemistry dan Kebun Biologi dapat digunakan sebagai sumber belajar bagi peserta didik.

Peneliti bermaksud untuk mengobservasi jenis-jenis tanaman yang ada di Green Chemistry dan Kebun Biologi UNIB. Selanjutnya hasil observasi ini akan dikembangkan menjadi bahan ajar cetak berupa LKPD materi keanekaragaman hayati, bidang tumbuhan. LKPD (student worksheet) adalah lembaran-lembaran berisi tugas yang harus dikerjakan oleh peserta didik. Lembar kegiatan ini biasanya berupa petunjuk, dan langkah-langkah untuk menyelesaikan suatu tugas (Depdiknas, 2008:13).

Berdasarkan pengamatan peneliti pada LKPD materi keanekaragaman hayati yang digunakan di sekolah dari berbagai penerbit yang berbeda, LKPD tersebut mempunyai beberapa kelemahan. Beberapa kelemahan tersebut antara lain: tampilan kurang menarik karena terkesan terlalu sederhana dan singkat; tidak disertai gambar atau ilustrasi yang beragam; gambar tidak berwarna; cakupan materi kurang lengkap; dan sebagian besar tidak memiliki komponen lengkap yang seharusnya dimiliki oleh suatu LKPD. LKPD yang baik adalah LKPD dengan materi yang sesuai kebutuhan peserta didik dan memiliki tampilan yang menarik minat peserta didik (Devi, 2013:36). Menurut Depdiknas (2008:24) LKPD yang baik adalah jika memiliki komponen penyusun yang lengkap.

Adapun tujuan dari penelitian ini adalah untuk mengetahui jenis-jenis tanaman yang terdapat di Green Chemistry dan Kebun Biologi Universitas Bengkulu dan untuk mengetahui kelayakan dan keterbacaan LKPD materi Keanekaragaman Hayati berdasarkan hasil observasi jenis-jenis tanaman yang terdapat di Green Chemistry dan Kebun Biologi Universitas Bengkulu. 
LKPD yang dihasilkan nantinya akan ditujukan kepada peserta didik kelas $X$ Sekolah Menengah Atas (SMA). Peserta didik kelas $X$ SMA merupakan peserta didik yang menerima pembelajaran materi keanekaragaman hayati di sekolah. Diharapkan melalui LKPD yang dihasilkan dapat memenuhi kompetensi dasar (KD) yaitu KD 3.2 menganalisis berbagai tingkat keanekaragaman hayati di Indonesia beserta ancaman dan pelestariannya dan KD 4.2 menyajikan hasil observasi berbagai tingkat keanekaragaman hayati di Indonesia dan usulan upaya pelestariannya. Melalui penelitian ini diharapkan diketahuinya dan tersedianya data mengenai jenis-jenis tanaman yang terdapat di Green Chemistry Universitas Bengkulu dan Kebun Biologi Universitas Bengkulu. Serta dapat mendesain LKPD berdasarkan jenis-jenis tanaman di Green Chemistry Universitas Bengkulu dan Kebun Biologi Universitas Bengkulu yang dapat memenuhi kompetensi yang diharapkan pada pembelajaran peserta didik materi keanekeragaman hayati.

\section{METODE}

Jenis penelitian ini adalah penelitian dan pengembangan atau Research and Development (R \& D). Penelitian ini dilakukan berdasarkan langkah-langkah penelitian dan pengembangan Sugiyono (2008:409) yang telah disesuaikan dengan kebutuhan peneliti. Langkah-langkah desain LKPD yang digunakan pada penelitian ini mengacu pada Depdiknas (2008:23-24) dengan beberapa modifikasi.

Penelitian ini dilakukan pada bulan Maret-Mei 2018 di Green Chemistry, Kebun Biologi, Universitas Bengkulu dan SMAN 8 Kota Bengkulu. Subjek penelitian ini adalah LKPD dan tanaman di Green Chemistry dan Kebun Biologi Universitas Bengkulu. Subjek Uji coba penelitian ini adalah siswa kelas X SMAN 8 Kota Bengkulu.

Teknik pengumpulan data yang digunakan pada penelitian ini adalah observasi, angket, dan literatur. Teknik observasi menggunakan lembar observasi digunakan untuk mengumpulkan data jenis tanaman. Teknik literatur menggunakan buku dan artikel ilmiah, digunakan untuk membandingkan data jenis tanaman dengan literatur. Teknik angket menggunakan lembar angket, digunakan pada uji validitas oleh 2 dosen dan satu guru Biologi SMA dan uji keterbacaan oleh peserta didik kelas X SMA. Analisis data jenis-jenis tanaman dilakukan secara deskriptif dan dibandingkan dengan berbagai literatur. Data uji validasi dan uji keterbacaan dipresentasekan untuk masingmasing responden menggunakan rumus:

Presentase $=\frac{\text { Jumlah skor lembar validasi }}{\text { Skor maksimal }} \times 100 \%$

Skor presentase selanjutnya dirataratakan dan diinterpretasikan pada kategori kualitatif dapat dilihat pada Tabel 1.

Tabel 1. Kriteria Interpretasi Skor

\begin{tabular}{cc}
\hline Presentase & Kriteria \\
\hline $0 \%-20 \%$ & Sangat Tidak Valid / Sangat \\
& Tidak Baik \\
$21 \%-40 \%$ & Tidak Valid / Tidak Baik \\
$41 \%-60 \%$ & Cukup Valid / Cukup Baik \\
$61 \%-80 \%$ & Valid / Baik \\
$81 \%-100 \%$ & Sangat Valid / Sangat Baik \\
\hline
\end{tabular}

\section{HASIL DAN PEMBAHASAN}

\section{Lembar Kegiatan Peserta Didik (LKPD)}

Berdasarkan hasil terdapat 73 jenis tanaman yang tergolong ke dalam 45 suku di Green Chemistry dan Kebun Biologi Universitas Bengkulu. Jenis tanaman yang terdapat di Green Chemistry berjumlah 50 jenis dan Kebun Biologi berjumlah 45 jenis. Terdapat 22 jenis tanaman yang sama terdapat di dua lokasi yaitu Green Chemistry dan Kebun Biologi.

Jenis LKPD yang dikembangkan dari penelitian ini adalah LKPD eskperimen. LKPD eksperimen yaitu LKPD praktis yang digunakan sebagai panduan kerja lapangan disertai dengan alat dan bahan yang akan digunakan. Hal ini sesuai dengan Devi (2009:32) yaitu, LKPD eksperimen berupa lembar kerja yang memuat petunjuk praktikum yang menggunakan alat-alat dan bahan-bahan. Perbandingan desain awal dan 
desain akhir (setelah uji validasi) LKPD dapat dilihat pada Gambar 1.

Pada cover LKPD terdapat judul, mata pelajaran, serta kelas peserta didik untuk memudahkan peserta didik mengetahui informasi dan kegiatan inti di dalam LKPD. Pada cover juga diletakkan beberapa gambar tumbuhan yang terdapat dilokasi penelitian yang bertujuan untuk membuat desain LKPD lebih menarik dan memotivasi peserta didik untuk mengetahui lebih lanjut mengenai LKPD tersebut. Menurut Kurniawan (2015:14) desain cover harus menarik karena peserta didik akan terlebih dahulu melihat tampilan cover LKPD. Pada isi LKPD terdapat beberapa komponen antara lain kompetensi dasar, tujuan, materi pokok, alat dan bahan, cara kerja, hasil, pertanyaan, dan kesimpulan. Sesuai dengan komponen LKPD yang baik menurut Depdiknas (2008:24).

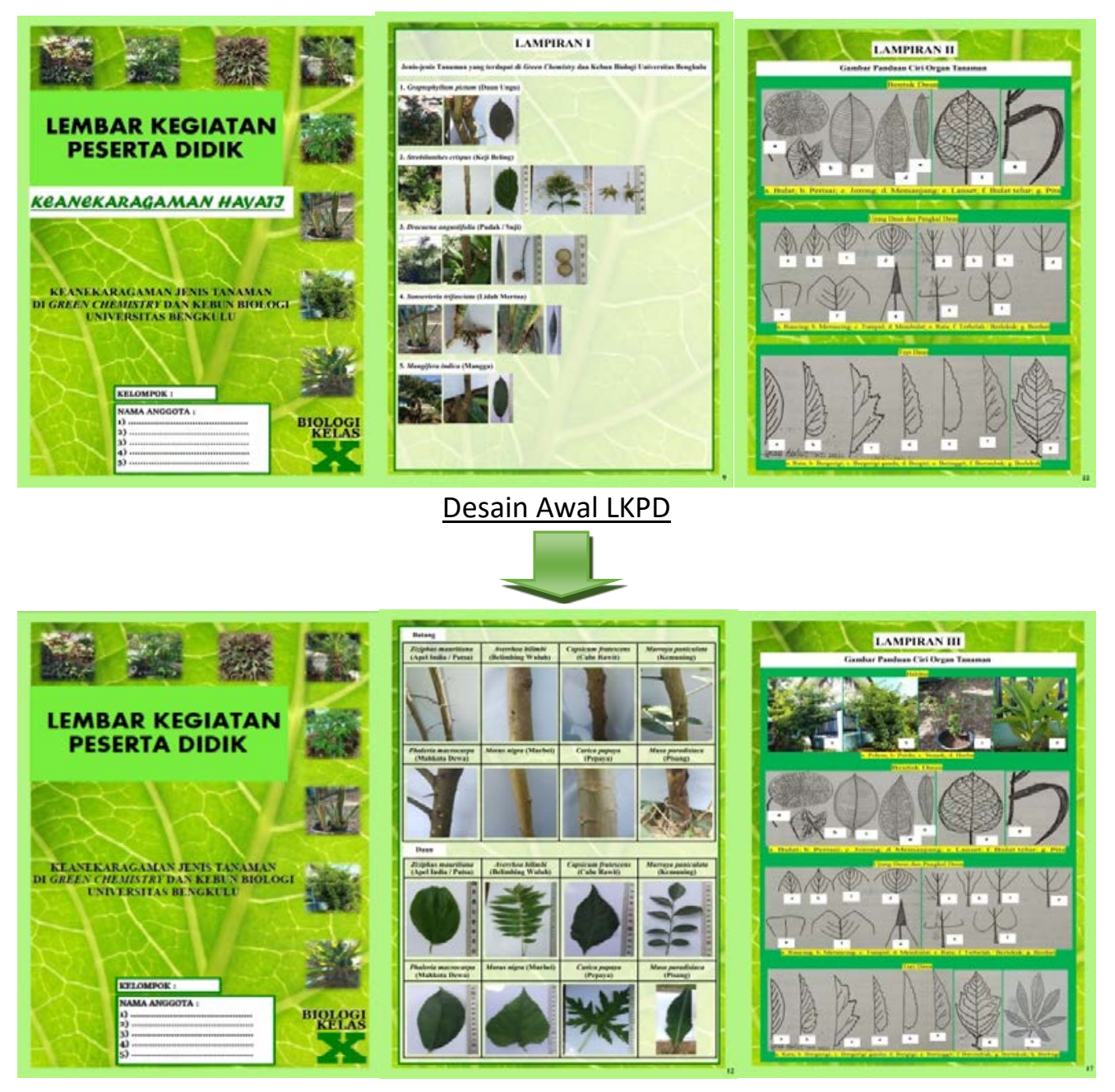

\section{Desain Akhir LKPD \\ Gambar 1. Perbandingan Desain Awal dan Desain Akhir LKPD}

Bagian lampiran LKPD memuat jenis-jenis tanaman lainnya yang tidak dibahas pada LKPD, dan gambar organ tanaman hasil penelitian yang terdapat di Green Chemistry dan Kebun Biologi Universitas Bengkulu yang akan diamati oleh peserta didik. LKPD juga disertai dengan lampiran gambar panduan ciri organ tanaman yang bertujuan untuk membantu peserta didik dalam melakukan pengamatan organ tanaman. Merujuk kepada panduan praktikum Team Kreatif Biologi (2016:86) suatu LKPD yang baik memiliki lembar panduan yang membantu peserta didik dalam proses pengamatan.

Keunggulan utama LKPD hasil pengembangan ini adalah dibuat berdasarkan penelitian dari objek lingkungan sekitar. Pemanfaatan lingkungan dapat 
mengembangkan sejumlah keterampilan, seperti mengamati (dengan seluruh indera), mencatat, merumuskan pertanyaan, berhipotesis, mengklasifikasikan, membuat tulisan, dan membuat gambar/diagram (Uno dan Mohamad, 2014:227-228). Hal ini didukung oleh pernyataan Zukmadini, dkk (2018) yang menyatakan bahwa keunggulan dari bahan ajar yang berbasis pada kearifan lokal adalah bersifat kontekstual, dekat dengan lingkungan siswa, dan tentunya materi yang disajikan tidak terlepas dari kesesuaian materi yang terdapat pada kurikulum.

Desain tampilan LKPD hasil pengembangan lebih menarik, gambar atau ilustrasi yang disajikan lebih beragam dan diberi warna sehingga lebih menarik minat peserta didik. Terbukti dengan hasil angket uji validitas oleh validator dengan skor diatas nilai minimum untuk sebagian besar aspek dapat dilihat pada Tabel 2. Hasil angket uji keterbacaan oleh peserta didik juga menunjukkan skor diatas rata-rata pada aspek penampilan (skor minimum 4). Menurut Salirawati (2004:5) penampilan sangat penting dalam LKPD karena pertama-tama peserta didik akan lebih tertarik dengan penampilan LKPD tersebut. Menurut Wibowo (2013:8) LKPD yang baik menggunakan lebih banyak ilustrasi dibandingkan dengan katakata.

Komponen penyusun LKPD hasil pengembangan disusun sesuai dengan komponen penyusun LKPD yang lengkap menurut Depdiknas (2008:24) yaitu terdiri dari judul, kompetensi dasar, tujuan, materi pokok, alat dan bahan, cara kerja, tabel hasil pengamatan, pertanyaan dan kesimpulan. Perbandingan beberapa komponen LKPD penerbit dengan LKPD hasil pengembangan dapat dilihat pada Gambar 2.

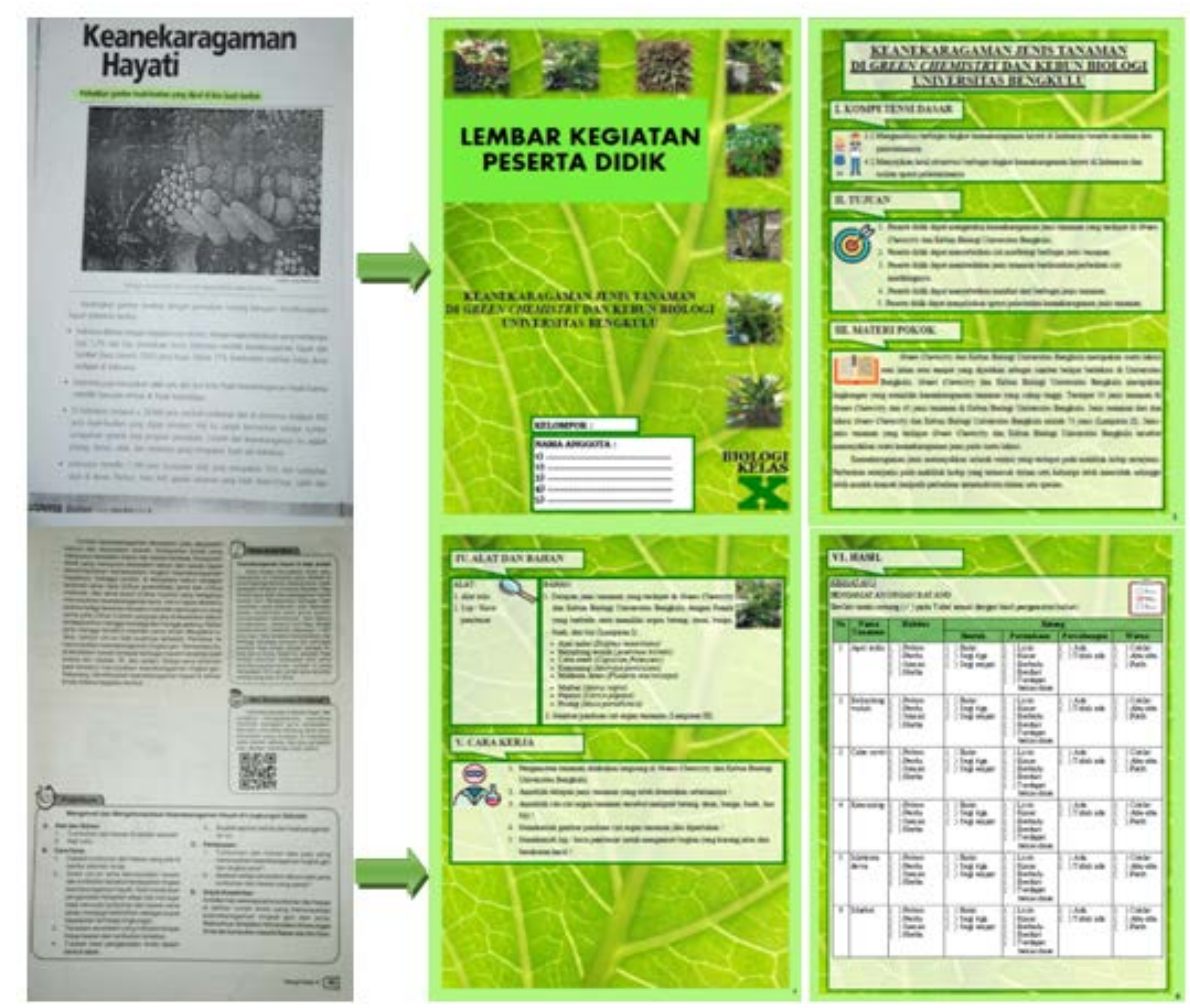

Gambar 2. Perbandingan Beberapa Komponen LKPD Penerbit dengan LKPD Hasil Pengembangan

\section{Uji Validitas LKPD}

Berdasarkan uji validitas, LKPD yang telah didesain memperoleh nilai rata-rata sebesar $88 \%$ dengan kriteria sangat valid (Tabel 2). Hal ini berarti bahwa ketiga validator menilai LKPD ini telah layak dari aspek materi, penyajian, kebahasaan, penampilan, dan desain grafis. Hal ini juga membuktikan bahwa 
LKPD ini telah didesain secara rasional dan lebih efektif, sesuai dengan tujuan uji validitas menurut Sugiyono (2008:414).

\section{Uji Keterbacaan LKPD}

Berdasarkan uji keterbacaan terhadap 15 peserta didik, LKPD yang telah didesain dikategorikan sangat baik dengan persentase
93\% dapat dilihat pada Tabel 3. Hal ini menandakan bahwa LKPD ini telah memenuhi persyaratan baik pada aspek penampilan, penyajian, materi, dan bahasa. Menurut Sugiyono (2008:414) uji keterbacaan dilakukan untuk melihat apakah LKPD tersebut sudah baik dan dapat digunakan dalam pembelajaran.

Tabel 2. Hasil Angket Uji Validitas LKPD oleh Validator

\begin{tabular}{|c|c|c|c|c|c|c|}
\hline \multirow{2}{*}{ No } & \multirow{2}{*}{ Validator } & \multirow{2}{*}{ Aspek Penilaian } & \multicolumn{2}{|c|}{ Skor } & \multirow{2}{*}{ Presentase } & \multirow{2}{*}{ Kriteria } \\
\hline & & & Minimal & Validator & & \\
\hline \multirow{5}{*}{1} & \multirow{5}{*}{$\begin{array}{c}\text { Validator I } \\
\text { (Dosen) }\end{array}$} & Kelayakan Materi & 21 & 33 & & \\
\hline & & Penyajian Materi & 15 & 23 & & \\
\hline & & Kebahasaan & & 29 & $93 \%$ & Sangat valid \\
\hline & & Penampilan & 15 & 23 & & \\
\hline & & Desain grafis & 36 & 60 & & \\
\hline \multirow{5}{*}{2} & \multirow{5}{*}{$\begin{array}{c}\text { Validator II } \\
\text { (Dosen) }\end{array}$} & Kelayakan Materi & 21 & 28 & & \\
\hline & & Penyajian Materi & 15 & 19 & & \\
\hline & & Kebahasaan & & 28 & $78 \%$ & Valid \\
\hline & & Penampilan & 15 & 19 & & \\
\hline & & Desain grafis & 36 & 48 & & \\
\hline \multirow{6}{*}{3} & & Kelayakan Materi & 21 & 33 & & \\
\hline & Validator III & Penyajian Materi & 15 & 24 & & \\
\hline & (Guru Biologi & Kebahasaan & & 32 & $95 \%$ & Sangat valid \\
\hline & SMA) & Penampilan & 15 & 23 & & \\
\hline & & Desain grafis & 36 & 60 & & \\
\hline & & Rerata & & & $88 \%$ & Sangat valid \\
\hline
\end{tabular}

Tabel 3. Hasil Angket Uji Keterbacaan LKPD oleh Peserta Didik

\begin{tabular}{ccccc}
\hline No & Responden & Skor & Presentase & Kriteria \\
\hline 1 & AMF & 21 & $100 \%$ & Sangat baik \\
2 & CA & 21 & $100 \%$ & Sangat baik \\
3 & DPA & 21 & $100 \%$ & Sangat baik \\
4 & F & 20 & $95 \%$ & Sangat baik \\
5 & MSR & 21 & $100 \%$ & Sangat baik \\
6 & M & 21 & $100 \%$ & Sangat baik \\
7 & MBP & 18 & $85 \%$ & Sangat baik \\
8 & MFP & 17 & $80 \%$ & Baik \\
9 & MW & 19 & $90 \%$ & Sangat baik \\
10 & MWN & 21 & $100 \%$ & Sangat baik \\
11 & NAP & 20 & $95 \%$ & Sangat baik \\
12 & RN & 20 & $95 \%$ & Sangat baik \\
13 & SNA & 19 & $90 \%$ & Sangat baik \\
14 & SA & 19 & $90 \%$ & Sangat baik \\
15 & YRP & 18 & $85 \%$ & Sangat baik \\
\hline
\end{tabular}


Sebagian besar peserta didik memberikan pendapat bahwa LKPD yang didesain memiliki cover yang menarik, gambar, tabel dan materi yang jelas dan menarik, dan isi LKPD mudah dipahami dan disajikan secara rinci. Secara keseluruhan peserta didik tertarik, termotivasi, menyukai, memahami, dan merasa LKPD tersebut dapat menambah wawasan dan pengetahuan mereka. Namun terdapat saran dari beberapa peserta didik yaitu untuk memperjelas bagian lampiran pada LKPD yaitu lampiran gambar panduan ciri organ tanaman. Peserta didik menyarankan agar bagian lampiran tersebut disertai dengan contoh jenis tanaman yang memiliki organ sesuai dengan gambar panduan ciri organ tersebut.

\section{PENUTUP}

\section{Simpulan}

Tanaman yang terdapat di Green Chemistry dan Kebun Biologi Universitas Bengkulu berjumlah 73 jenis tanaman yang tergolong ke dalam 45 suku. Lembar Kegiatan Peserta Didik (LKPD) materi Keanekaragaman Hayati yang telah didesain berdasarkan hasil validasi LKPD dinyatakan termasuk ke dalam kriteria sangat valid dengan presentase $88 \%$. LKPD ini juga dinyatakan sangat baik dengan presentase $93 \%$ dalam uji keterbacaan.

\section{Saran}

Lembar Kegiatan Peserta Didik (LKPD) yang telah didesain dapat digunakan untuk penelitian selanjutnya yaitu penelitian implementasi atau penerapan bahan ajar untuk peserta didik kelas $X$ SMA materi Keanekaragaman Hayati.

\section{Daftar Pustaka}

Depdiknas. 2008. Panduan Pengembangan Bahan Ajar. Jakarta: Direktorat Pembinaan Sekolah Menengah Atas.

Devi, P.K., R. Sofiraeni, Khairuddin. 2009. Pengembangan Perangkat Pembelajaran untuk Guru SMP. Bandung: PPPPTK IPA.
Kurniawan, Agus. 2015. Pengembangan Lembar Kerja Peserta Didik, (www.respository.ump.ac.id diakses 23 Juli 2018).

Mustofa, M., S. Ngabekti, R.S. Iswari. 2013. Pengembangan Lembar Kerja Siswa Berbasis Observasi pada Taman Sekolah Sebagai Sumber Belajar Sains. Unnes Journal of Biology Education (www.journal.unnes.ac.id diakses 7 November 2017).

Nurhayati, N., R. Wijayanti. 2016. Biologi untuk SMA/MA Kelas X. Bandung: Yrama Widya.

Prastowo, A. 2011. Panduan Kreatif Membuat Bahan Ajar Inovatif. Jogjakarta: Diva Press.

Republika. 2012. Sekolah Dilarang Jual Belikan LKS, (www.republika.co.id diakses 29 November 2017).

Riduwan. 2015. Skala Pengukuran Variabelvariabel Penelitian. Bandung: Alfabeta.

Salirawati, Das. 2004. Penyusunan dan Kegunaan LKS dalam Proses Pembelajaran, (www.staffnew.uny.ac.id diakses 23 Juli 2018).

Sugiyono. 2008. Metode Penelitian Pendidikan (Pendekatan Kuantitatif, Kualitatif, dan R\&D). Bandung: Alfabeta.

Team Kreatif Biologi. 2016. Panduan Praktikum Biologi SMA/MA Kelas X. Jakarta: Bumi Aksara.

Uno, H.B., N. Mohamad, 2014. Belajar dengan Pendekatan PAILKEM. Jakarta: Bumi Aksara.

Wibowo, W.S. 2013. Pengembangan Perangkat Pembelajaran IPA Terpadu Guna Mendukung Pelaksanaan Kurikulum 2013. Makalah disajikan dalam PPM "Workshop Pengembangan Perangkat Pembelajaran IPA Terpadu bagi Guru SMP/MTs, Depok, 7 Agustus.

Zukmadini, Alif Yanuar., Jumiarni, Dewi., Kasrina. 2018. Developing 
Antimicrobial Medicinal Plants Pocketbook Based on Local Wisdom of Muko-Muko and Serawai Ethnics. Jurnal Pendidikan Biologi Indonesia. 4 (2): 95-104. http://ejournal.umm.ac.id/index.ph $\mathrm{p} / \mathrm{jpbi} /$ article/view/5436. Diakses 5 Desember 2018 